\title{
Keragaman Genetik Galur Harapan Kacang Bambara (Vigna subterranea (L.) Verdc.)
}

\author{
Genetic Diversity of Bambara Groundnut (Vigna subterrania (L.) Verdc.) lines
}

\author{
Siti Fatimah ${ }^{1}$, Ariffin ${ }^{2}$, Ardiarini Noer Rahmi ${ }^{2}$, dan Kuswanto ${ }^{2 *}$ \\ ${ }^{1}$ Fakultas Pertanian Universitas Trunojoyo Madura, Jl. Raya Telang PO BOX 2, Kamal, Bangkalan, Jawa Timur \\ ${ }^{2}$ Fakultas Pertanian Universitas Brawijaya Malang, Jl. Veteran Malang, Jawa Timur \\ *Email korespondensi: kuswantoas@ub.ac.id
}

Diterima: 9 September 2020 / Disetujui: 30 September 2020

\begin{abstract}
The main problem in developing bambara groundnut in Indonesia at the moment is low productivity at the farm level, one of which is caused by planting loca lines with high diversity. One solution to solve this problem is by making superior varieties tha utilize existing local lines through single seed descent selection. This study aims to determine genetic diversity among of bambara groundnut lines based on quantitative mophological character data. The study used 11 bambara groundnut lines selected from lokal strains from East Java and West Java. The results showed that there was divesity among the lines evaluated in the character of growth and yield. Characters that have high heritability are number of leaves, terminal leaf width, terminal leaf lenght, petiole lenght, internode lenght, fresh weight of residues, number of flowers, number of stem segments, number of pod, fresh weight per pod, dry weight of residues, pod lenght, number of seeds.
\end{abstract}

Keywords : Bambara groundnut, Madura line, genetics diversity, single seed descent, heritability.

\section{ABSTRAK}

Permasalahan utama dalam pengembangan kacang bambara di Indonesia adalah rendahnya produktivitas di tingkat petani yang disebabkan oleh penanaman galur lokal dengan tingkat keragaman yang tinggi. Salah satu solusi yang bisa dilakukan adalah dengan merakit varietas unggul dengan memanfaatkan galur-galur lokal yang ada melalui seleksi, misalnya metode seleksi single seed descent (SSD). Penelitian ini bertujuan untuk mengetahui keragaman genetik di antara galur-galur harapan kacang bambara hasil seleksi single seed descent berdasarkan data kuantitatif karakter morfologi. Penelitian menggunakan 11 galur harapan hasil seleksi SSD galur-galur lokal kacang bambara dari daerah sentra penanaman di Jawa Timur dan Jawa Barat dan satu galur pembanding koleksi Laboratorium Pemuliaan Tanaman Fakultas Pertanian Universitas Brawijaya Malang. Penelitian menggunakan Rancangan Acak Lengkap (RAL) dengan 3 ulangan. Hampir semua parameter pertumbuhan yang diamati menunjukkan adanya keragaman diantara dua belas galur harapan yang diuji, tetapi tidak menunjukkan adanya keragaman pada parameter hasil. Karakter yang mempunyai nilai heritabilitas dalam arti luas kategori tinggi (>50\%-100\%) adalah karakterjumlah daun, lebar daun terminal, panjang daun terminal, panjang petiole, panjang internode, bobot brangkasan basah, jumlah bunga, jumlah ruas, jumlah polong, bobot polong per polong, bobot brangkasan kering, panjang polong dan jumlah biji.

Kata Kunci: Kacang bambara, keragaman genetik, seleksi single seed descent, heritabilitas.

\section{PENDAHULUAN}

Kacang bambara atau Bambara groundnut (Vigna subterranea L.Verdc.) adalah salah satu tanaman legume yang berasal dari Afrika dan telah tersebar di India, Sri Lanka, Indonesia, Filipina, Malaysia, Kaledonia Baru dan Amerika Selatan. Di Indonesia, tanaman kacang bambara termasuk salah satu kacang-kacangan minor yang belum terlalu diperhatikan, namun memiliki peran dalam program diversifikasi pangan. Menurut Kuswanto et al. (2012), kacang bambara banyak dibudidayakan hanya di Jawa Barat dan sebagian kecil dikembangkan di wilayah Jawa Timur, Jawa Tengah dan NTT. Sejak tahun 2006, tanaman ini sudah digolongkan sebagai salah satu tanaman pangan binaan pemerintah berdasarkan Surat Keputusan Menteri Pertanian No:511/kpts/PD/310/9/2006.

Menurut (Suwanprasert et al., 2006), kacang bambara adalah termasuk tanaman legum yang berpotensi sebagai salah satu sumber pangan alternatif masa depan, karena didalam biji keringnya mengandung $16-21 \%$ protein, 50-60\% karbohidrat dan 4,5-6,5\% lemak, serta mengandung kalsium, fosfor, zat besi dan vitamin B1. Menurut Berchie et al., (2012), kemampuannya untuk tumbuh dan berkembang baik pada kondisi lingkungan yang kering dan kurang subur menjadi salah satu keunggulan tanaman legum ini. Berdasarkan potensi di atas, maka tanaman kacang bambara diharapkan juga berpotensi untuk dikembangkan di lahan kering seperti Madura. 
Kendala utama yang dihadapi dalam pengembangan kacang bambara di Madura dan daerah lain di Indonesia adalah produktivitas di tingkat petani masih rendah. Hasil penelitian (Redjeki, 2003) menunjukkan bahwa penanaman dengan menggunakan berbagai warna biji menghasilkan biji kering 0,7 sampai 2,0 ton per hektar. Potensi genetik tanaman ini mampu mencapai hasil 4,0 ton per hektar biji kering pada kondisi lingkungan tumbuh yang optimal (Kouassi \& Zoro Bi, 2010).

Salah satu penyebab rendahnya produktivitas di tingkat petani adalah saat ini tanaman yang ditanam masih menggunakan galur lokal dengan tingkat keragaman yang tinggi. Hasil penelitian Kuswanto et. al. (2011) menunjukkan bahwa dari 50 galur lokal kacang bambara yang berasal dari Jawa Timur dan Jawa Barat terdapat keragaman yang tinggi baik keragaman antar galur maupun keragaman dalam galur yang diuji, meliputi karakter tipe tumbuh tanaman, bentuk daun dan rambut pada batang. Sehingga kegiatan pemuliaan tanaman perlu segera dilakukan untuk memperbaiki galurgalur lokal tersebut, salah satunya dilakukan seleksi galur lokal dan purifikasi galur lokalyang potensial. Selanjutnya galur-galur tersebut dihaharapkan dapat dikembangkan menjadi varietas baru atau sebagai tetua persilangan.

Proses penggaluran kacang bambara jenis lokal dari berbagai daerah di Indonesia termasuk dari Madura sudah dimulai sejak tahun 2012, yang diawali dengan kegiatan pemurnian berdasarkan karakter polong dan biji yang dilanjutkan dengan kegiatan seleksi. Evaluasi kemurnian dan keragaman pada setiap tahap seleksi juga telah dilakukan dengan tujuan untuk memilih galur-galur harapan yang mempunyai tingkat keseragaman dalam galur dan keragaman antar galur yang tinggi.

Upaya meningkatkan keseragaman galur-galur hasil purifikasi telah diterapkan dengan metode seleksi Single Seed Descent (SSD I) pada tahun 2014 (Nuryati, Soegianto, 2014). Hasil menunjukkan bahwa diperoleh 5 (lima) populasi galur hasil SSD-1 memiliki matriks kemiripan lebih dari 0,80 dan 15 (lima belas) populasi galur sisanya masih memiliki matriks kemiripan kurang dari 0,80 (Arif et al., 2016). Sehingga masih diperlukan kegiatan seleksi untuk meningkatkan keseragaman dari masing-masing galur.

Kegiatan seleksi SSD-2 juga telah dilakukan pada tahun 2015 dengan hasil bahwa telah terjadi peningkatan keseragaman dalam galur dari populasi galur-galur harapan hasil seleksi, yaitu diperoleh 17 galur harapan dengan nilai keseragaman dalam galur kategori baik (kemiripan 80\% $90 \%$ ) pada karakter kualitatif, serta satu galur dengan nilai keseragaman dalam galur sangat baik (kemiripan lebih 90\%) (Nugraha, 2015). Hal ini menunjukkan bahwa sebagian besar populasi galur hasil SSD-2 sudah dapat dikategorikan sebagai galur murni.

Keragaman genetik diantara galur harapan yang diperoleh sangat penting untuk kegiatan pemuliaan tanaman berikutnya dan nilai heritabilitas merupakan sarana untuk menduga apakah keragaman karakter yang terjadi lebih banyak dipengaruhi oleh faktor genetik atau faktor lingkungannya. Keragaman dari karakter yang memiliki nilai heritabilitas dalam arti luas rendah dan sedang belum tentu akan diwariskan ke generasi berikutnya karena proporsi pengaruh lingkungan terhadap penampilan karakter ini lebih besar atau sama dengan pengaruh genetiknya. Sehingga jika dilakukan seleksi terhadap karakter-karakter ini kurang efektif. Berdasarkan data di atas, maka dilakukan penelitian ini yang bertujuan untuk mengetahui keragaman genetik di antara galur-galur harapan kacang bambara hasil seleksi dan nilai heritabilitasnya.

\section{BAHAN DAN METODE}

Penelitian dilaksanakan di lahan petani di Desa Pagesangan Kecamatan Jambangan Kota Surabaya, mulai bulan Desember 2016 - Mei 2017. Bahan yang digunakan dalam penelitian ini adalah 11 galur harapan kacang bambara hasil proses penggaluran dari galur-galur lokal yang berasal dari berbagai daerah di Indonesia dan satu galur pembanding koleksi Laboratorium Pemuliaan Tanaman Fakultas Pertanian Universitas Brawijaya Malang (UB Cream) (Tabel 1). Pupuk yang digunakan adalah Urea $100 \mathrm{~kg} / \mathrm{ha}$, SP $36100 \mathrm{~kg} / \mathrm{ha}, \mathrm{KCl}$ $75 \mathrm{~kg} / \mathrm{ha}$ dan pupuk kandang. Bahan untuk menanggulangi hama digunakan pestisida Decis. Alat-alat pertanian yang dipakai antara lain : pot plastik, cangkul, sekop, penggaris, kantong kertas, label, jangka sorong elektrik, timbangan digital, kamera, alat tulis.

Penelitian ini disusun menggunakan Rancangan Acak Lengkap (RAL), dengan satu faktor genotipa kacang bambara diulang 3 kali. Parameter pengamatan meliputi umur tanaman terdiri dari umur muncul kecambah, umur muncul daun pertama, umur muncul bunga pertama dan umur panen. Parameter pertumbuhan meliputi jumlah daun, tinggi tanaman, diameter tajuk, tebal daun, lebar daun terminal, panjang daun terminal, panjang petiole dan panjang internode yang diamati pada saat tanaman berumur 10 minggu setelah tanam. Parameter komponen hasil dan hasil meliputi jumlah bunga, jumlah cabang, jumlah ruas, jumlah polong, bobot polong basah per tanaman, bobot per polong, bobot polong kering per tanaman, lebar polong, panjang polong, jumlah biji, bobot biji per tanaman, bobot per biji, produktivitas polong basah per hektar, dan produktivitas biji per hektar. Parameter lain yang diamati antara lain panjang akar, bobot brangkasan basah, bobot brangkasan kering per tanaman, bobot kulit dan shelling percentage. Data yang diperoleh dianalisis ragam menggunakan uji $\mathrm{F}$ pada taraf nyata $5 \%$ dan apabila terdapat pengaruh nyata, pengujian dilanjutkan menggunakan DMRT (Duncan Multiple Range Test) pada taraf $5 \%$.

\section{HASIL DAN PEMBAHASAN}

Seleksi adalah salah satu cara perakitan varietas unggul baru dari populasi campuran, yang bertujuan untuk meningkatkan homosigositas atau membuat galur seragam. Dalam perakitan varietas unggul melalui metode seleksi, maka evaluasi keragaman antar galur harapan hasil seleksi mempunyai peranan penting. Karena adanya keragaman di antara galur harapan hasil seleksi memberikan peluang untuk mengembangkan galur-galur harapan tersebut menjadi galurgalur unggul baru, baik melalui kegiatan seleksi lagi maupun persilangan. 
Berdasarkan hasil evaluasi keragaman terhadap 12 galur harapan kacang bambara hasil seleksi menunjukkan bahwa perlakuan genotip berpengaruh nyata pada hampir semua karakter pertumbuhan vegetatif tanaman (Tabel 2), kecuali pada karakter pertumbuhan panjang akar dan jumlah cabang. Genotipa juga berpengaruh nyata pada karakter hasil, yaitu jumlah polong per tanaman dan bobot polong basah per tanaman. Tidak menunjukkan pengaruh nyata pada karakter bobot polong kering per tanaman, bobot biji per tanaman dan produtivitas biji per hektar. Artinya bahwa di antara 12 galur harapan yang diuji menunjukkan adanya keragaman pada karakter pertumbuhan vegetatif tanaman, jumlah polong dan bobot polong basah per tanaman. Data ini menunjukkan bahwa galur-galur harapan hasil seleksi yang diuji sangat dimungkinkan bisa dikembangkan menjadi galur-galur unggul baru kacang bambara, baik melalui kegiatan seleksi selanjutnya maupun dijadikan sebagai tetua dalam kegiatan persilangan.

Umur muncul kecambah, Umur muncul daun pertama, Umur muncul bunga pertama dan umur panen.

Stadia muncul kecambah dan munculnya daun pertama di antara 12 galur harapan kacang bambara yang diuji tidak menunjukkan adanya keragaman. Nilai rata-rata umur muncul kecambah 6,86 hari setelah tanam dan rata-rata umur muncul daun pertama adalah 9,39 hari setelah tanam. Data ini menunjukkan bahwa rata-rata umur muncul kecambah pada penanaman di lahan kering Madura, yang ditanam pada musim kemarau berkecambah lebih cepat. Hasil penelitian (Enen et al., 2016) menunjukkan bahwa stadia perkecambahan kacang bambara yang ditanam di lapang berkisar antara 8-10 hst. (Berchie et al., 2010) bahwa kacang bambara tergolong memiliki masa perkecambahan lama, antara 7-15 hst.

Dalam penelitian ini menunjukkan bahwa terdapat keragaman pada karakter umur muncul bunga pertama dan umur panen di antara 12 galur harapan yang diuji. Dua belas galur harapan yang diuji mulai muncul bunga pertama berkisar antara 38,33 - 48,33 hst. Hasil penelitian (Enen et al., 2016) bahwa terbentuknya bunga pertama pada umur 39 hst. Tetapi aksesiaksesi yang berasal dari Burkina Faso Afrika mulai muncul bunga pertama lebih pendek, berkisar antara 30-33 hst (Ouedraogo et al., 2008). Dalam penelitian ini, galur harapan hasil seleksi dari galur lokal Madura (JLB1) dan dari kabupaten Lamongan (BBL 2.1.1) mempunyai umur muncul bunga pertama terpendek (38,33 hst). Sedangkan galur harapan yang berasal dari Laboratorium Pemuliaan Tanaman Fakultas Pertanian Universitas Brawijaya (UB Cream) mempunyai umur muncul bunga pertama terpanjang $(48,33$ hst). Sedangkan untuk karakter umur panen, galur harapan yang berasal dari Laboratorium Pemuliaan Tanaman Fakultas Pertanian Universitas Brawijaya (UB Cream) mempunyai umur panen yang terpanjang (153,33 hst) dan galur harapan yang berasal dari Madura (TKB1) mempunyai umur panen terpendek (127 hst).

Jumlah Daun; Tinggi Tanaman; Diameter Tajuk; Tebal Daun; Lebar Daun Terminal; Panjang Daun Terminal;

\section{Panjang Internode; Panjang Petiole;}

Pengamatan karakter vegetatif tanaman meliputi jumlah daun, tinggi tanaman, diameter tajuk, tebal daun, lebar daun terminal, panjang daun terminal, panjang internode dan panjang tangkai daun atau petiole dilakukan pada saat tanaman berumur 10 minggu setelah tanam. Galur pembanding yang merupakan koleksi Laboratorium Pemuliaan Tanaman Fakultas Pertanian Universitas Brawijaya (UB Cream) secara umum menunjukkan pertumbuhan vegetatif tanaman paling tinggi. Jumlah daun di antara 12 galur garapan kacang bambara yang diuji berkisar 86,33 - 150,67. Galur harapan dari Kecamatan Bungah Kabupaten Gresik (PWBG 5.3.1) mempunyai jumlah daun paling banyak $(150,67)$ tidak berbeda dengan galur pembanding (UB Cream), sedangkan galur harapan yang berasal dari Cianjur (CCC2.1.1) mempunyai jumlah daun paling sedikit $(86,33)$. Daun merupakan tempat berlangsungnya fotosintesis tanaman, berarti jumlah daun semakin banyak maka fotosintat yang dihasilkan tanaman juga akan semakin banyak. Dalam penelitian ini, galur harapan PWBG mempunyai jumlah daun paling banyak dan juga memiliki jumlah polong banyak (83,33 polong per tanaman). Hasil yang sama juga ditunjukkan dalam penelitian (Enen et al., 2016) bahwa aksesi Sukabumi testa hitam adalah aksesi yang memiliki jumlah daun dan jumlah polong paling banyak. Tetapi keadaan ini tidak terjadi pada galur harapan yang berasal dari Laboratorium Pemuliaan Tanaman Fakultas Pertanian Universitas Brawijaya (UB Cream), meskipun memiliki jumlah daun paling banyak tetapi galur harapan ini memiliki jumlah polong paling sedikit. Di antara 12 galur harapan yang diuji tidak menunjukkan adanya keragaman pada karakter tebal daun, dan galur harapan yang berasal dari Cianjur (CCC 2.1.1.) merupakan galur yang memiliki daun terminal paling lebar.

Jumlah Cabang, Jumlah Ruas, Jumlah Bunga, Jumlah Polong per tanaman, Bobot Polong per tanaman.

Pengamatan jumlah cabang dan jumlah ruas dilakukan pada saat panen, dan menunjukkan bahwa tidak adanya keragaman di antara 12 galur harapan kacang bambara yang diuji pada karakter jumlah cabang dan jumlah ruas. Jumlah cabang dari 12 galur harapan kacang bambara yang diuji berkisar antara $6-9$ cabang per tanaman dan jumlah ruas pada masing-masing cabang berkisar antara 7-18 ruas per cabang. Pengamatan jumlah bunga dilakukan setiap hari, setiap pukul 10.00 - 12.00 WIB, karena bunga kacang bambara mulai mekar pada pukul 08.00 pagi dan mulai layu pada pukul 12.00 siang. Hasil penelitian ini menunjukkan bahwa terdapat keragaman pada karakter jumlah bunga di antara 12 galur harapan yang diuji. Hasil yang sama diperoleh pada penelitian (Fatimah et al., 2020) bahwa karakter jumlah bunga kacang bambara beragam. Galur pembanding yang berasal dari Laboratorium Pemuliaan Tanaman Fakultas Pertanian Universitas Brawijaya (UB Cream) mempunyai jumlah bunga paling banyak (565,33 bunga), sedangkan galur harapan hasil seleksi dari galur lokal Madura (CKB-1) mempunyai jumlah bunga paling sedikit 143,67. Karakter 
jumlah polong menunjukkan bahwa terdapat keragaman di antara 12 galur harapan kacang bambara yang diuji dengan nilai rata-rata jumlah polong 60,14 polong per tanaman. Hasil penelitian (Ning Fias et al., 2015) juga menunjukkan adanya keragaman pada karakter jumlah polong. Galur pembanding (UB Cream) mempunyai jumlah polong paling sedikit $(29,67$ polong per tanaman, sedangkan galur harapan (CKB-1) mempunyai jumlah polong terbanyak $(86,00$ polong per tanaman). Dibandingkan dengan jumlah bunga yang terbentuk, galur harapan CKB-1 mempunyai kemampuan untuk membentuk polong terbanyak, yaitu $59,86 \%$ bunga yang terbentuk dapat menjadi polong, sedangkan galur pembanding UB Cream hanya 5\% dari jumlah bunga yang terbentuk bisa menjadi polong. Penelitian yang sama juga diperoleh Nugraha (2015) bahwa pada galur pembanding UB Cream hanya $9 \%$ dari bunga yang terbentuk $(245,45$ bunga per tanaman) dapat menjadi polong. Dalam peneitian ini tidak menunjukkan adanya keragaman pada karakter bobot polong per tanaman dan rata-rata bobot polong per tanaman sebesar 83,81 gram per tanaman.

\section{Bobot brangkasan basah per tanaman, Bobot brangkasan kering per tanaman, Panjang akar}

Karakter bobot brangkasan basah dan panjang akar tidak menunjukkan adanya keragaman di antara 12 galur harapan yang diuji. Rata-rata bobot brangkasan basah di antara 12 galur harapan kacang bambara diuji sebesar 76,89 gram per tanaman dan rata-rata panjang akar sebesar 13, 32 $\mathrm{cm}$. Tetapi untuk karakter bobot brangkasan kering menunjukkan adanya keragaman diantara 12 galur harapan yang diuji, dan galur pembanding UB Cream mempunyai bobot brangkasan kering paling banyak dan berbeda dengan 11 galur harapan yang diuji.

\section{Bobot per polong, panjang polong dan lebar polong}

Karakter kualitas polong yang diamati meliputi bobot per polong, panjang dan lebar polong. Di antara 12 galur harapan yang diuji tidak menunjukkan adanya keragaman pada karakter panjang dan lebar polong. Rata-rata panjang polong sebesar 18,65 $\mathrm{mm}$ dan lebar polong sebesar $14,74 \mathrm{~mm}$. Rata-rata bobot per polong di antara 12 galur harapan diuji sebesar 1,42 gram. Galur harapan yang berasal dari Cianjur Jawa Barat mempunyai bobot polong tertinggi sebesar 2,12 gram dan galur harapan dari Madura CKB-1 mempunyai bobot polong terkecil, sebesar 1,04 gram. Hal ini menunjukkan bahwa galur harapan dari Madura (CKB-1) mempunyai polong kecil dan galur harapan dari Cianjur Jawa Barat mempunyai polong besar.

\section{Nilai Heritabilitas}

Keragaman yang terjadi pada suatu karakter dipengaruhi oleh faktor genetik dan faktor lingkungan dimana tanaman itu tumbuh. Besaran proporsi dari pengaruh faktor genetik dan faktor lingkungan terhadap keragaman karakter tersebut dapat diketahui dengan cara menghitung nilai duga heritabilitas karakter tersebut. Karakter mempunyai nilai duga heritabilitas tinggi artinya bahwa keragaman karakter tersebut lebih banyak dipengaruhi oleh faktor genetik daripada karena faktor lingkungannya. Menurut Stanfield (1983) pengelompokan nilai duga heritabilitas arti luas menjadi 3 kriteria, yaitu nilai heritabilitas kriteria tinggi apabila nilai antara $0,50-1,00$, kriteria sedang apabila nilai duga heritabilitas antara 0,2 -0,50 dan kriteria rendah apabila nilai duga heritabilitas kurang dari 0,20. Hasil penelitian ini menunjukkan bahwa nilai duga heritabilitas dalam arti luas dari semua karakter yang diamati dari 12 genotipa kacang bambara berkisar 0,09 - 0,90. Hal ini menunjukkan bahwa nilai heritabilitas pada penelitian ini masuk kriteria rendah sampai kriteria tinggi (Tabel 3). Menurut Bahar dan Zen (1993), Puspodharsono (1988) bahwa nilai duga heritabilitas dalam arti luas yang tinggi menunjukkan pengaruh genetik lebih besar terhadap penampilan fenotipe dibandingkan dengan pengaruh lingkungan. Sebaliknva nilai duga heritabilitas dalam arti luas yang rendah menunjukkan pengaruh faktor lingkungan lebih besar terhadap penampilan fenotipe dibandingkan faktor genetiknya.

Tabel 3 menunjukkan bahwa karakter yang mempunyai nilai heritabilitas dalam arti luas rendah (kurang dari 0,20) adalah hanya karakter umur kecambah. Karakter yang mempunyai nilai heritabilitas dalam arti luas kategori sedang $(0,20-0,50)$ adalah karakter umur keluar daun pertama, umur berbunga, jumlah hari panen, tinggi tanaman, tebal daun, diameter tajuk, panjang akar, jumlah cabang, bobot polong per tanaman, hasil polong per ha, bobot polong kering per tanaman, lebar polong, bobot biji per tanaman, shelling percentage, hasil biji per ha, bobot kulit dan bobot per biji. Karakter yang memiliki nilai duga heritabilitas dalam arti luas rendah dan sedang belum tentu akan diwariskan ke generasi berikutnya karena proporsi pengaruh lingkungan terhadap penampilan karakter ini lebih besar atau sama dengan pengaruh genetiknya, sehingga jika dilakukan seleksi terhadap karakter-karakter ini kurang efektif.

Karakter yang yang mempunyai nilai heritabilitas dalam arti luas kategori tinggi (lebih dari 0,5-1,00) dalam penelitian ini adalah karakter jumlah daun, lebar daun terminal, panjang daun terminal, panjang petiole, panjang internode, bobot brangkasan basah, jumlah bunga, jumlah ruas, jumlah polong, bobot polong per polong, bobot brangkasan kering, panjang polong dan jumlah biji. Hasil penelitian (Austi \& Damanhuri, 2014) juga menunjukkan bahwa karakter panjang daun, panjang tangkai daun dan jumlah bunga mempunyai nilai heritabilitas tinggi. Menurut Khan et al. (2009) bahwa nilai heritabilitas yang tinggi akan membantu kegiatan seleksi berdasarkan fenotipe. (Dhanwani et al., 2013) menambahkan bahwa karakter dengan nilai heritabilitas tinggi menunjukkan bahwa ekspresi karakter yang diamati lebih banyak (Dhanwani et al., 2013)(Dhanwani et al., 2013) dipengaruhi faktor genetik dan hanya sedikit dipengaruhi faktor lingkungan, sehingga berpeluang untuk diwariskan ke generasi selanjutnya. 
Tabel 1. Daftar asal galur harapan kacang bambara

\begin{tabular}{|c|c|c|c|c|c|c|c|}
\hline No. & Kode & $\begin{array}{l}\text { Nama } \\
\text { Galur }\end{array}$ & Asal & No & Kode & Nama Galur & Asal \\
\hline 1. & G1 & GSG 1.1.1 & Gresik & 7 & G7 & GSG 2.1.1 & Gresik \\
\hline 2. & $\mathrm{G} 2$ & GSG 2.4 & Gresik & 8 & G8 & JLB 1 & Bangkalan Madura \\
\hline 3. & G3 & GSG 3.1.2 & Gresik & 9 & G9 & CKB 1 & Bangkalan Madura \\
\hline 4. & G4 & BBL 2.1.1 & Lamongan & 10 & G10 & TKB 1 & Bangkalan Madura \\
\hline 5. & G5 & BBL 6.1.1 & Lamongan & 11 & G11 & PWBG 5.3.1 & Gresik \\
\hline 6. & G6 & CCC 2.1.1 & Cianjur & 12 & G12 & UB Cream & $\begin{array}{c}\text { Lab Pemuliaan Fakultas } \\
\text { Pertanian UB }\end{array}$ \\
\hline
\end{tabular}

Tabel 2. Nilai rata-rata, Nilai Kuadrat Tengah, F hitung hasil anova dan koefisien keragaman karakter morfologi kuantitatif 12 galur harapan kacang bambara hasil seleksi.

\begin{tabular}{|c|c|c|c|}
\hline Karakter & Rata & F hit & KK \\
\hline Umur kecambah (hst) & 6,86 & $1,29 \mathrm{~ns}$ & 10,53 \\
\hline Umur keluar daun (hst) & 9,39 & $2,02 \mathrm{~ns}$ & 14,40 \\
\hline Umur berbunga (hst) & 41,86 & $2,40 *$ & 4,55 \\
\hline Umur panen (hst) & 135,94 & $3,16 * *$ & 3,18 \\
\hline Jumlah daun & 104,22 & $12,29 * *$ & 6,74 \\
\hline Tinggi tanaman $(\mathrm{cm})$ & 27,64 & $3,42 * *$ & 5,62 \\
\hline Diameter tajuk (cm) & 57,19 & $2,44 *$ & 6,07 \\
\hline Tebal daun (mm) & 0,14 & $3,54 * *$ & 14,04 \\
\hline Lebar daun terminal $(\mathrm{cm})$ & 2,67 & $20,37 * *$ & 3,36 \\
\hline Panjang daun terminal $(\mathrm{cm})$ & 7,89 & $9,26 * *$ & 3,14 \\
\hline Panjang petiole $(\mathrm{cm})$ & 18,45 & $14,21 * *$ & 4,17 \\
\hline Panjang internode (cm) & 2,73 & $5,54 * *$ & 6,08 \\
\hline Panjang akar (cm) & 13,32 & $1,95 \mathrm{~ns}$ & 8,64 \\
\hline Bobot brangkasan basah (g) & 76,89 & $11,29 * *$ & 15,84 \\
\hline Jumlah bunga & 227,69 & $25,04 * *$ & 4,55 \\
\hline Jumlah cabang & 7,94 & $1,97 \mathrm{~ns}$ & 10,86 \\
\hline Jumlah ruas & 9,2 & $27,11 * *$ & 6,26 \\
\hline Jumlah polong & 60,14 & $* *$ & 15,77 \\
\hline Bobot polong per tan $(\mathrm{g})$ & 83,81 & $*$ & 21,07 \\
\hline Hasil polong per ha (t/ha) & 9,31 & $*$ & 23,38 \\
\hline Bobot per polong (g) & 1,42 & $* *$ & 11,12 \\
\hline Lebar polong (mm) & 14,74 & $*$ & 6,80 \\
\hline Panjang polong (mm) & 18,65 & $* *$ & 5,33 \\
\hline Jumlah biji & 59,58 & $* *$ & 18,58 \\
\hline Bobot biji per tan (g) & 29,47 & ns & 24,02 \\
\hline Shelling Percentage (\%) & 22 & $* *$ & 8,21 \\
\hline Hasil biji per ha (t/ha) & 3,27 & $\mathrm{~ns}$ & 24,02 \\
\hline Bobot kulit (g) & 8,27 & ns & 23,98 \\
\hline Bobot per biji (g) & 0,5 & $*$ & 14,78 \\
\hline
\end{tabular}

Keterangan : $*$ = berbeda nyata pada taraf $5 \%, * *=$ berbeda nyata pada taraf $1 \%, \mathrm{tn}=$ tidak nyata 
Tabel 3: Nilai Tengah karakter morfologi 12 galur harapan kacang bambara

\begin{tabular}{|c|c|c|c|c|c|c|c|c|c|c|c|c|c|c|}
\hline Galur & Kode & UK & UB & UP & JD & & DT & TD & LDT & PDT & PINTER & $\mathbf{P P t}$ & JC & JR \\
\hline GSG 1.1.1 & G1 & 7.33 & $40.67 \mathrm{bc}$ & $139.67 \mathrm{~b}$ & 87.67 & c & $57.00 \mathrm{~b}$ & 0.14 & $2.59 \mathrm{bc}$ & $8.56 \mathrm{ab}$ & $2.96 \mathrm{~b}$ & 18.23 bcde & 7.00 & 8.22 \\
\hline GSG 2.4 & $\mathrm{G} 2$ & 6.67 & $39.67 \mathrm{bc}$ & $132.33 \mathrm{cb}$ & 93.33 & $\mathrm{c}$ & $57.67 \mathrm{~b}$ & 0.14 & $2.37 \mathrm{~cd}$ & $8.66 \mathrm{a}$ & $2.60 \mathrm{bcd}$ & 17.94 bcde & 7.00 & 8.56 \\
\hline GSG 3.1.2 & G3 & 6.67 & $40.67 \mathrm{bc}$ & $135.00 \mathrm{cb}$ & 93.67 & $\mathrm{c}$ & $52.67 \mathrm{~b}$ & 0.17 & $2.43 \mathrm{~cd}$ & $7.87 \mathrm{bc}$ & $2.48 \mathrm{~cd}$ & $16.39 \mathrm{e}$ & 9.33 & 9.00 \\
\hline BBL 2.1.1 & G4 & 6.33 & $38.33 \mathrm{c}$ & $132.00 \mathrm{cb}$ & 98.33 & $\mathrm{c}$ & $60.00 \mathrm{ab}$ & 0.11 & $2.59 \mathrm{bc}$ & $8.67 \mathrm{a}$ & $2.54 \mathrm{bcd}$ & $18.60 \mathrm{bcd}$ & 8.67 & 8.22 \\
\hline BBL 6.1.1 & G5 & 6.33 & $39.33 \mathrm{bc}$ & $134.67 \mathrm{cb}$ & 119.67 & $\mathrm{~b}$ & $57.67 \mathrm{~b}$ & 0.11 & $2.30 \mathrm{~d}$ & 7.42 cde & $2.89 \mathrm{bc}$ & 17.70 bcde & 7.33 & 8.78 \\
\hline CCC 2.1.1 & G6 & 5.67 & $42.00 \mathrm{abc}$ & $131.00 \mathrm{cb}$ & 86.33 & $\mathrm{c}$ & $52.67 \mathrm{~b}$ & 0.10 & $3.20 \mathrm{a}$ & 7.53 cde & $2.67 \mathrm{bcd}$ & $19.13 \mathrm{bc}$ & 8.33 & 6.67 \\
\hline GSG 2.1.1 & G7 & 7.67 & $44.67 \mathrm{abc}$ & $137.33 \mathrm{cb}$ & 87.33 & $\mathrm{c}$ & $51.33 \mathrm{~b}$ & 0.10 & $2.19 \mathrm{~d}$ & $7.57 \mathrm{~cd}$ & $2.52 \mathrm{bcd}$ & 17.54 cde & 6.33 & 8.22 \\
\hline JLB 1 & G8 & 7.33 & $38.33 \mathrm{c}$ & $134.67 \mathrm{cb}$ & 91.00 & $\mathrm{c}$ & $62.33 \mathrm{ab}$ & 0.18 & $2.69 \mathrm{~b}$ & $8.64 \mathrm{a}$ & $2.81 \mathrm{bc}$ & $19.66 \mathrm{~b}$ & 7.00 & 9.22 \\
\hline CKB 1 & G9 & 6.33 & $43.33 \mathrm{abc}$ & $138.33 \mathrm{cb}$ & 104.33 & $\mathrm{bc}$ & $54.67 \mathrm{~b}$ & 0.10 & $3.11 \mathrm{a}$ & $6.94 \mathrm{de}$ & $2.61 \mathrm{bcd}$ & 17.39 cde & 9.00 & 8.00 \\
\hline TKB 1 & G10 & 7.33 & $46.00 \mathrm{ab}$ & $127.00 \mathrm{c}$ & 97.33 & $\mathrm{c}$ & $51.33 \mathrm{~b}$ & 0.19 & $3.07 \mathrm{a}$ & 6.76 & $2.32 \mathrm{~d}$ & $17.04 \mathrm{de}$ & 9.67 & 7.44 \\
\hline PWBG 5.3.1 & G11 & 6.67 & $41.00 \mathrm{bc}$ & $136.00 \mathrm{cb}$ & $150.67 \mathrm{a}$ & & $59.33 \mathrm{ab}$ & 0.12 & $2.43 \mathrm{~cd}$ & 7.27 cde & $2.79 \mathrm{bc}$ & $16.76 \mathrm{de}$ & 9.00 & 9.78 \\
\hline UB Bream & G12 & 8.00 & $48.33 \mathrm{a}$ & $153.33 \mathrm{a}$ & $141.00 \mathrm{a}$ & & $69.67 \mathrm{a}$ & 0.15 & $3.03 \mathrm{a}$ & $8.86 \mathrm{a}$ & $3.53 \mathrm{a}$ & $25.07 \mathrm{a}$ & 8.00 & 18.33 \\
\hline
\end{tabular}

Tabel 4: Nilai Tengah karakter morfologi 12 galur harapan kacang bambara

\begin{tabular}{|c|c|c|c|c|c|c|c|c|c|c|}
\hline Galur & Kode & JB & $\mathbf{P A}$ & BBB & $\mathbf{J P}$ & $\mathrm{BP} / \mathrm{T}$ & $\mathbf{B P} / \mathbf{P}$ & PP & $\mathbf{L P}$ & BBK/T \\
\hline GSG 1.1.1 & G1 & $176.00 \mathrm{~cd}$ & 14.17 & 51.33 & $42.67 \mathrm{de}$ & 55.00 & $1.29 \mathrm{bcd}$ & 16.75 & 13.49 & $24.17 \mathrm{c}$ \\
\hline GSG 2.4 & $\mathrm{G} 2$ & $246.33 \mathrm{bc}$ & 15.27 & 60.67 & $67.33 \mathrm{abc}$ & 84.33 & $1.25 \mathrm{~cd}$ & 18.07 & 13.96 & $26.27 \mathrm{bc}$ \\
\hline GSG 3.1.2 & G3 & $173.67 \mathrm{~cd}$ & 12.77 & 60.67 & $71.67 \mathrm{ab}$ & 82.67 & $1.15 \mathrm{~d}$ & 18.76 & 15.11 & $25.57 \mathrm{bc}$ \\
\hline BBL 2.1.1 & G4 & $190.67 \mathrm{~cd}$ & 13.70 & 86.00 & 51.67 bcde & 90.00 & $1.74 \mathrm{ab}$ & 19.39 & 15.61 & $28.13 \mathrm{bc}$ \\
\hline BBL 6.1.1 & G5 & $292.00 \mathrm{~b}$ & 13.00 & 79.00 & $71.33 \mathrm{ab}$ & 106.33 & $1.49 \mathrm{bcd}$ & 18.56 & 14.81 & $29.73 \mathrm{bc}$ \\
\hline CCC 2.1.1 & G6 & $144.33 \mathrm{~d}$ & 10.73 & 53.33 & 46.33 cde & 98.00 & $2.12 \mathrm{a}$ & 20.69 & 19.02 & $20.67 \mathrm{c}$ \\
\hline GSG 2.1.1 & G7 & $157.33 \mathrm{~d}$ & 12.17 & 50.00 & $53.67 \mathrm{bcd}$ & 80.00 & $1.49 \mathrm{bcd}$ & 17.83 & 14.35 & $21.80 \mathrm{c}$ \\
\hline JLB 1 & G8 & $221.00 \mathrm{bcd}$ & 14.40 & 83.67 & 49.33 bcde & 60.00 & $1.22 \mathrm{bcd}$ & 18.32 & 14.51 & $30.30 \mathrm{bc}$ \\
\hline CKB 1 & G9 & $143.67 \mathrm{~d}$ & 14.50 & 63.33 & $86.00 \mathrm{a}$ & 120.67 & $1.40 \mathrm{bcd}$ & 18.22 & 14.87 & $25.93 \mathrm{bc}$ \\
\hline TKB 1 & G10 & $155.33 \mathrm{~d}$ & 12.50 & 65.33 & $68.67 \mathrm{abc}$ & 71.33 & $1.04 \mathrm{~d}$ & 16.54 & 13.21 & $22.37 \quad \mathrm{c}$ \\
\hline PWBG 5.3.1 & G11 & $268.67 \mathrm{~b}$ & 12.60 & 103.00 & $83.33 \mathrm{a}$ & 104.00 & $1.25 \mathrm{bcd}$ & 17.74 & 14.71 & $36.87 \mathrm{~b}$ \\
\hline UB Bream & G12 & $563.33 \mathrm{a}$ & 14.00 & 166.33 & 29.67 & 53.33 & $1.80 \mathrm{abc}$ & 21.19 & 14.93 & $87.63 \mathrm{a}$ \\
\hline
\end{tabular}

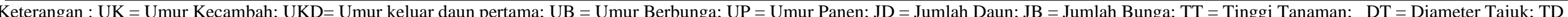
$=$ Tebal Daun LDT $=$ Lebar Daun Terminal PDT = Panjang Daun Terminal; PINTER = Panjang Internode $;$ PPt $=$ Panjang Petiole; JC = Jumlah Cabang; PA = Panjang Akar $; \mathrm{BBB}=\mathrm{Berat}$ Brangkasan Basah; JR = Jumlah Ruas; JP = Jumlah Polong; BP $/ \mathrm{T}=$ Bobot Polong Basah per Tanaman; BP/P= Bobot per polong; BPK $/ \mathrm{T}=\mathrm{Bobot}$ polong kering per tanaman; BBK = Bobot Brangkasan Kering; PP = Panjang Polong; LP = Lebar Polong 
Tabel 3. Nilai Ragam Fenotip, Ragam Genetik, Ragam Lingkungan, dan nilai Heritabilitas dalam arti luas karakter kuantitatif 12 galur harapan kacang bambara hasil seleksi.

\begin{tabular}{|c|c|c|c|c|c|}
\hline Karakter & $\sigma^{2} p$ & $\sigma^{2} \mathrm{e}$ & $\sigma^{2} g$ & $\mathbf{H}$ & Kriteria \\
\hline Umur kecambah (hst) & 1,16 & 1,06 & 0,10 & 0,09 & Rendah \\
\hline Umur keluar daun (hst) & 1,12 & 0,83 & 0,28 & 0,25 & Sedang \\
\hline Umur berbunga (hst) & 18,11 & 12,33 & 5,78 & 0,32 & Sedang \\
\hline Jumlah hari panen (hst) & 68,43 & 39,78 & 28,66 & 0,42 & Sedang \\
\hline Jumlah daun & 540,59 & 113,44 & 427,14 & 0,79 & Tinggi \\
\hline Tinggi tanaman $(\mathrm{cm})$ & 9,80 & 5,42 & 4,39 & 0,45 & Sedang \\
\hline Diameter tajuk $(\mathrm{cm})$ & 51,40 & 34,69 & 16,71 & 0,33 & Sedang \\
\hline Tebal daun (mm) & 0,00 & 0,00 & 0,00 & 0,46 & Sedang \\
\hline Lebar daun terminal $(\mathrm{cm})$ & 0,13 & 0,02 & 0,12 & 0,87 & Tinggi \\
\hline Panjang daun terminal $(\mathrm{cm})$ & 0,68 & 0,18 & 0,50 & 0,73 & Tinggi \\
\hline Panjang petiole $(\mathrm{cm}) \mathrm{t}$ & 5,98 & 1,11 & 4,87 & 0,81 & Tinggi \\
\hline Panjang internode $(\mathrm{cm})$ & 0,13 & 0,05 & 0,08 & 0,60 & Tinggi \\
\hline Panjang akar $(\mathrm{cm})$ & 3,18 & 2,42 & 0,77 & 0,24 & Sedang \\
\hline Bobot basah brangkasan (g) & 1240,18 & 279,81 & 960,37 & 0,77 & Tinggi \\
\hline Jumlah bunga & 14727,22 & 1633,75 & 13093,47 & 0,89 & Tinggi \\
\hline Jumlah cabang & 2,72 & 2,06 & 0,66 & 0,24 & Sedang \\
\hline Jumlah ruas & 9,59 & 0,99 & 8,60 & 0,90 & Tinggi \\
\hline Jumlah polong & 392,75 & 146,72 & 246,03 & 0,63 & Tinggi \\
\hline Bobot polong per tan $(\mathrm{g})$ & 860,56 & 607,58 & 252,98 & 0,29 & Sedang \\
\hline Hasil polong per ha $(\mathrm{t} / \mathrm{ha})$ & 10,62 & 7,50 & 3,12 & 0,29 & Sedang \\
\hline Bobot per polong $(\mathrm{g})$ & 0,14 & 0,07 & 0,07 & 0,51 & Tinggi \\
\hline Bobot polong kering per $\tan (\mathrm{g})$ & 170,65 & 131,85 & 38,80 & 0,23 & Sedang \\
\hline Bobot brangkasan kering (g) & 358,05 & 41,02 & 317,03 & 0,89 & Tinggi \\
\hline Lebar polong (mm) & 1,96 & 1,28 & 0,68 & 0,35 & Sedang \\
\hline Panjang polong $(\mathrm{mm})$ & 3,66 & 1,21 & 2,45 & 0,67 & Tinggi \\
\hline Jumlah biji & 442,26 & 164,17 & 278,09 & 0,63 & Tinggi \\
\hline Bobot biji per tan $(g)$ & 106,92 & 82,69 & 24,23 & 0,23 & Sedang \\
\hline Shelling Percentage $(\%)$ & 14,38 & 7,98 & 6,40 & 0,45 & Sedang \\
\hline Hasil biji per ha (t/ha) & 1,32 & 1,02 & 0,30 & 0,23 & Sedang \\
\hline Bobot kulit (g) & 9,63 & 7,44 & 2,19 & 0,23 & Sedang \\
\hline Bobot per biji (g) & 0,01 & 0,01 & 0,01 & 0,36 & Sedang \\
\hline
\end{tabular}

Keterangan : $\sigma^{2} \mathrm{p}=$ ragam fenotipe, $\sigma^{2} \mathrm{e}=$ ragam lingkungan, $\sigma^{2} \mathrm{~g}=$ ragam genetik dan $\mathrm{H}=$ nilai duga heritabilitas dalam arti luas

\section{KESIMPULAN}

Berdasarkan penelitian ini dapat disimpulkan bahwa menunjukkan adanya keragaman pertumbuhan dan hasil di antara galur-galur harapan kacang bambara hasil seleksi. Karakter yang mempunyai nilai duga heritabilitas tinggi adalah jumlah daun, lebar daun terminal, panjang daun terminal, panjang petiole, panjang internode, bobot brangkasan basah, jumlah bunga, jumlah ruas, jumlah polong, bobot polong per polong, bobot brangkasan kering, panjang polong dan jumlah biji.

\section{UCAPAN TERIMA KASIH}

Penulis mengucapkan terima kasih kepada
Kemenristek Dikti yang telah memberi bantuan dana Hibah Penelitian Disertasi Doktor Tahun 2017.

\section{DAFTARPUSTAKA}

Arif, A., Kendarini, N., \& Kuswanto. (2016). Evaluation of genetic purity on 20 genotypes of Bambara groundnut ( Vigna subterranea L . Verdcourt ) selected from single seed descent morphological characters. Jurnal Produksi Tanaman, 4(3), 169-173. http://protan.studentjournal.ub.ac.id/index.php/protan/ article/view/277/268

Austi, I. R., \& Damanhuri. (2014). Keragaman dan kekerabatan pada proses penggaluran kacang bogor ( 
Vigna subterranea L. Verdcourt ) jenis lokal.

Berchie, J. N., Adu-Dapaah, H., Sarkodie-Addo, J., Asare, E., Agyemang, A., Addy, S., \& Donkor, J. (2010). Effect of seed priming on seedling emergence and establishment of four bambara groundnut (Vigna subterranea L. Verdc.) landraces. Journal of Agronomy, 9(4), 180-183. https://doi.org/10.3923/ja.2010.180.183

Dhanwani, R. K., Sarawgi, A. K., Solanki, A., \& Tiwari, J. K. (2013). Genetic variability analysis for various yield attributing and genetic variability analysis for various yield attributing and quality traits in rice (O. sativa L.). Supplement on Genetics \& Plant Breeding, 8(4), 14031407.

Enen, R., Manggung, R., Qadir, A., \& Ilyas, S. (2016). Fenologi, Morfologi, dan Hasil Empat Aksesi Phenology, Morphology, and Yield of Four Bambara. 44(1), 47-54.

Fatimah, S., ARIFFIN, A., RAHMI, A. N., \& KUSWANTO, K. (2020). Tolerance and determinants of drought character descriptors of the Madurese landrace bambara groundnut (Vigna subterranea). Biodiversitas Journal of Biological Diversity, 21(7), 3108-3116. https://doi.org/10.13057/biodiv/d210731

Kouassi, N. J., \& Zoro Bi, I. A. (2010). Effect of sowing density and seedbed type on yield and yield components in bambara groundnut (Vigna Subterranea) in woodland savannas of Cote D'ivoire. Experimental Agriculture, $\quad 46(1), \quad 99-110$. https://doi.org/10.1017/S0014479709990494
Ning Fias, N. A., Purnamaningsih, S. L., \& Kuswanto, K. (2015). An Agronomical characters on 18 selected genotypes of Bambara groundnut (Vigna Subterranea (L.) VERDCOURT). Jurnal Produksi Tanaman, 3(2). http://protan.studentjournal.ub.ac.id/index.php/protan/ article/view/195

Nuryati, Soegianto, A. and K. (2014). Genetik relationship and variability among Indonesian purified local lines of Bambara groundnut (Vigna subterranea ( L .) Verdc .) based on morphological characters. 3, 18-24.

Ouedraogo, M., Ouedraogo, J., Tignere, J., Bilma, D., Dabire, C., \& Konate, G. (2008). Characterization and evaluation of accessions of Bambara groundnut (Vigna subterranea (L.) Verdcourt) from Burkina Faso. Sciences \& Nature, 5(2), 191-197. https://doi.org/10.4314/scinat.v5i2.42164

Redjeki, E. S. (2003). Pengaruh seleksi galur murni pada populasi campuran terhadap hasil tanaman kacang bogor ( Vigna subterranea ( L .) Verdcourt ). Agrofish, 3(1412), 97-105.

Redjeki, E.S., (2007). Pertumbuhan dan Hasil TanamanKacang Bogor (Vigna subterranean (L.) Verdcourt) Galur Gresik dan Bogor Pada BerbagaiWarnaBiji. Prosiding Seminar Nasional Hasil Penelitian. P. 114-118.

Singh, R.K. and B.D. Chaudhary. (1979). Biometrical Methods in Quantitative Genetic Analysis. Kalyani Publishers. New Delhi. 304p

Suwanprasert, J., T. Toojinda, P. Srivines, S. Chanprame. (2006). Hybridization technique for bambara groundnut. Breeding Science, 56, 125-129. 